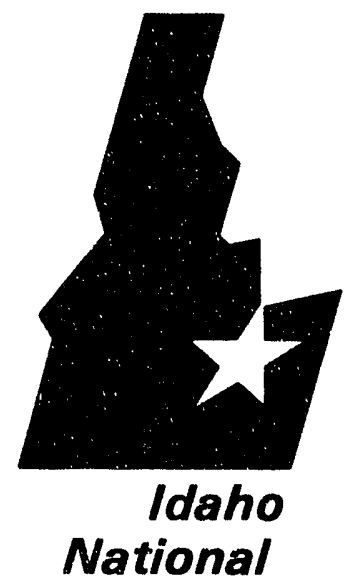

Engineering Laboratory

\section{Managed}

by the U.S.

Department

of Energy
EGG-FSP-10346

July 1992

REACTION OF POROUS BERYLLIUM IN STEAM
G. R. Smolik

B. J. Merrill

R. S. Wallace

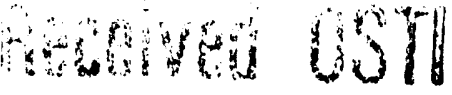 \\ OCT 261992
}

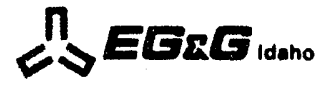

Work performed under No. DE-AC07-761D01570 


\section{DISCLAIMER}

This hook was prepared as an account of work sponsored by an agency of the United States Government. Neither the United States Government nor any agency thereof. nor any of their employees. makes any warranty, express or implied. or assumes any legal liability or responsibility for the accuracy, completeness. or usafulness of any information, apparatus, product or process disclosed, or represents that its usa would not intringe privately owned rights. References herein to any specific commercial product, process, or service by trade name. trademark, mantsfacturer, or otherwise. does not necesserily constitute or imply its endorsement, recommendation, of favoring by the United States Government or any agency thereof. The views and opinions of authors expressed herein do not necessarily state or reflect those of the United States Government or any agency thereof. 


\title{
REACTION OF POROUS BERYLLIUM IN STEAM
}

\section{Fusion Safety Program/Activation Products Task}

\author{
G. R. Smolik, B. J. Merrill and R. S. Wallace
}

Published July 1992

Idaho National Engineering Laboratory

EG\&G Idaho, Inc.

Idaho Falls, Idaho 83415



MASTER

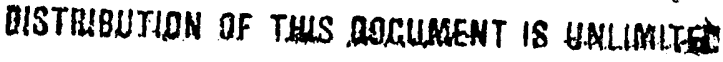




\section{ABSTRACT AND SUMMARY}

This report presents the findings of some additional investigations into the reaction of beryllium of approximately $88 \%$ theoretical density with steam. An earlier investigation ${ }^{1}$ had shown this material to be extremely reactive compared to dense beryllium. Inductively heated samples developed selfsustaining reactions due to the exothermic heat of reaction at temperatures between $600^{\circ} \mathrm{C}$ and $700^{\circ} \mathrm{C}$. These initial tests did not compleiely explain the mechanisms causing this behavior. The onset of thermal instability appeared to have a temperature dependent incubation period and some dependence upon specimen geometry. Additional tests have clarified this behavior. We have also obtained measurements of emissivity and permeability. This information will be helpful in the future in modeling reactor accident scenarios. The high effective surface area of porous beryllium has also allowed reaction rates to be obtained at temperatures as low as $400^{\circ} \mathrm{C}$. This information for porous beryllium was then used to extend relationships for the reaction rates of dense beryllium in steam to these lower temperatures. 


\section{CONTENTS}

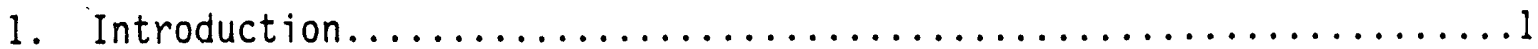

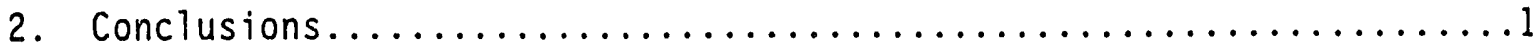



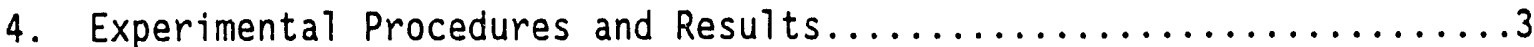

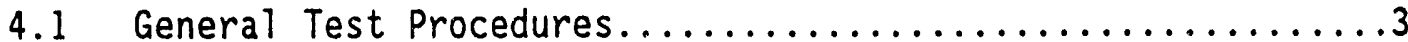



4.3 Radiatively Heated Samples (Temperature Dependence)........6

4.4 Radiatively Heated Samples (Geometry Dependence)............10

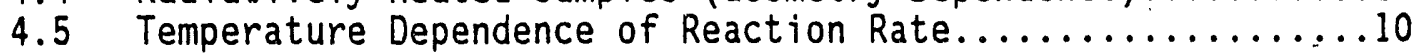

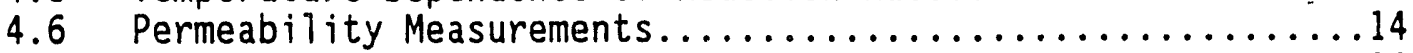

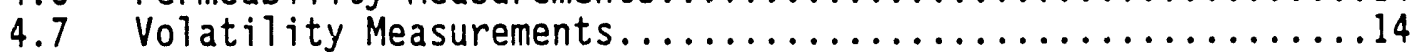

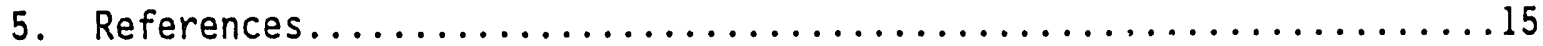




\section{INTRODUCTION}

Beryllium has attractive features for use both in first wall components and in the breeding blanket of fusion reactors. Different forms of beryllium have different possibilities for use such as dense beryllium in blankets and plasma facing components (PFCs), plasma-sprayed in PFC components, and porous beryllium components in the blanket. A concern, however, is the reaction of beryllium with high temperature steam resulting from an accident that injects water into the plasma chamber. We have previously investigated the reactions of dense and $88 \%$ dense beryllium in steam from $600^{\circ} \mathrm{C}$ to $1230^{\circ} \mathrm{C}$. " The investigation showed that the porous beryllium was significantly more reactive. Data at that time indicated that porous beryllium was about 200 times more reactive than dense beryllium. Samples of the porous material al so became thermally unstable. Exothermic heat of reaction caused samples to spontaneously react when inductively heated at targeted temperatures of greater than or equal to $600^{\circ} \mathrm{C}$. This behavior, although not completely understood, appeared to show some dependence upon time and specimen geometry.

Additional tests have been performed upon porous beryllium. The purposes of these tests were: a) to use the higher effective surface area of porous beryllium to obtain reaction rates for beryllium in steam below $600^{\circ} \mathrm{C}$, b) to obtain a better understanding of conditions causing the thermal instability in porous beryllium, and c) to add to our porous beryllium volatility database. Permeability and emissivity were two parameters measured to assist in the second objective and to contribute to the database for future modeling efforts of reactor transients. Specimens of different geometries were tested in a resistance heated furnace where the mode of sample heating is by radiative heat. This allowed us to check for the influences of property changes, such as electrical resistance, which might impact the extent of heating caused by an induction field. This report presents the findings from these investigations.

\section{CONCLUSIONS}

1. The threshold temperature for the onset of thermal instability for the porous bery 11 ium is between $650^{\circ} \mathrm{C}$ and $675^{\circ} \mathrm{C}$. This temperature is common for both inductively and radiatively heated specimens. Earlier indications of temperature dependent incubation periods and geometry influences upon the onset of thermal instability, some as low as $600^{\circ} \mathrm{C}$, were incorrect and caused by invalid temperature indications and control inherent to the experiments using induction heating.

2. Reactior. rates of porous ieryllium with steam depend both upon surface area and sample miass. Surface area initially provides the closest representation of reaction rates expressed as hydrogen production (liters $/ \mathrm{m}^{2}-\mathrm{s}$ ). However, as the reaction proceeds the samples develop greater porosity. This enhances the access of steam within the specimen resulting in a greater relative proportion of the 
reaction occurring within the specimen. Reaction rates ( 1 iters $/ \mathrm{m}^{2}-\mathrm{s}$ ), consequently, increased relative to initial rates based upon external surface area.

3. The slope for the reaction rates of porous beryllium on the reciprocal temperature plot is not exactly parallel to that for dense beryllium as suggested previously. "This is likely related to the phenomena expressed in Item 2 , i.e., greater relative amounts of reaction occur internally with progressively longer times and at lower temperatures.

4. Volatility was quite low for the porous beryli ium specimens tested at temperatures below $600^{\circ} \mathrm{C}$.

\section{RECOMMENDATIONS}

The results from this investigation have provided the basis for the following recommendations.

1. Porous beryllium of approximately $88 \%$ full density becomes thermally unstable near $675^{\circ} \mathrm{C}$. From a safety point of view, it would be best to avoid using this form of beryllium because it is high reactivity. If the use of this material is unavoidable, its use should be limited to temperatures sufficiently below this threshold temperature, e.g., $600^{\circ} \mathrm{C}$ if exposure to steam is possible.

2. The reaction rate for the porous beryllium from $400^{\circ} \mathrm{C}$ to $700^{\circ} \mathrm{C}$ in terms of [1iters $\mathrm{H}_{2}(\mathrm{STP}) / \mathrm{m}^{2}-\mathrm{s}$ ] may be represented by Equation (1). Temperature is expressed as degrees $K$.

$$
\begin{gathered}
\text { Reaction Rate }\left(1 \text { iters } / \mathrm{m}^{2}-s\right)=12.3 \times 10^{4} \mathrm{e}^{-12,500 / \mathrm{T}}, \\
\text { Temperatures: } 2400^{\circ} \mathrm{C} \leq 700^{\circ} \mathrm{C}
\end{gathered}
$$

3. Reaction rates for dense beryllium can be represented for temperatures from $600^{\circ} \mathrm{C}$ to $900^{\circ} \mathrm{C}$ by Equation (2) shown below and reported in Reference 1 . The constant $R$ is $8.317 \mathrm{~J} / \mathrm{mole}-\mathrm{K}$ and temperature ( $T$ ) is expressed as degrees $K$.

$$
\begin{gathered}
\text { Reaction Rate ( Iiters } \left./ \mathrm{m}^{2}-\mathrm{s}\right)=4.8 \times 10^{9} \mathrm{e}^{-215,000 / R T} \text {, } \\
\text { Temperatures: } 2600^{\circ} \mathrm{C} \leq 900^{\circ} \mathrm{C}
\end{gathered}
$$

For reaction rates of dense beryllium at temperatures below $600^{\circ} \mathrm{C}$, and for a measure of conservatism, we recommend using Equation (i) developed for porous beryllium divided by a factor of 100 . Thus reaction rates for dense beryllium below $600^{\circ} \mathrm{C}$ may be expressed as Equation (3).

$$
\begin{gathered}
\text { Reaction Rate ( } 1 \text { iters } / \mathrm{m}^{2}-\mathrm{s} \text { ) }=12.3 \times 10^{2} \mathrm{e}^{-12,500 / \mathrm{T}}, \\
\text { Temperatures: } 5600^{\circ} \mathrm{C}
\end{gathered}
$$


4. The emissivity measured for porous beryllium when initially exposed was near 0.25 and increased with exposure. This value of 0.25 was obtained from a single wavelength $(1.65 \mu \mathrm{m})$ and at an angle of approximately 30 degrees from normal. This adds to the database but additional information for total emittance would be needed for use in thermal modeling.

5. The permeability of gases in porous beryllium has been determined. The constant $\left(K_{a}\right)$ characteristic for this material was found to be 0.98 millidarceys. The following relationship, Equation (4), is recommended for use when applying this constant in modeling other gases and geometries.

$$
K_{a}(0.98 \text { millidarceys })=(M Q L) /(A \Delta P) \times 1000
$$

$M$ is the viscosity of the gas in centipoise. $Q$ is flow rate $\left(\mathrm{cm}^{3} / \mathrm{s}\right), L$ is sample length $(\mathrm{cm})$. A is sample area in $\mathrm{cm}^{2} . \Delta P$ is the absolute pressure drop across sample in atmospheres. A centidarcey is a flow of $0.01 \mathrm{~cm}^{3} / \mathrm{s}$ of a fluid with one centipoise viscosity through a $1-\mathrm{cm}$ cube under a pressure difference of one atmosphere.

\section{EXPERIMENTAL PROCEDURES AND RESULTS}

\subsection{General Test Procedures}

Tests in steam were performed in two different test set-ups having many similar conditions. One system provided induction heating and was contained in a glove box as described in Reference 1. The other system provided radiative heating in a $36-\mathrm{cm}$ long muffle furnace contained in a ventilated hood. Both systems had a gas-tight glassware assembly which allowed the samples to be purged with argon and preheated. Tests were initiated by switching to $470^{\circ} \mathrm{C}$ preheated steam supplied at $0.17 \mathrm{~g} / \mathrm{s}$. Both test chambers were $6.4 \mathrm{~cm}$ in diameter and produced a steam velocity of $0.26 \mathrm{~m} / \mathrm{s}$ at the specimen surface. Samples were then heated to the targeted temperature. Steam temperatures did not increase significantly above $470^{\circ} \mathrm{C}$ for experiments using induction heating, however, the steam was heated to approximately the targeted test temperatures in the muffle furnace. Gas flow was directed through a condensing system and into a collection system. Complete recondensation of steam al lowed hydrogen, the residual product gas, to be used as a means to measure reaction rates. The various glassware components were cleaned with acid solutions and analyzed with inductively coupled plasma atomic emission spectroscopy (I $)$-AES) to check for the possible transport of beryllium oxidation products.

The porous material used for this investigation had the same background as that used for our previous investigation. 1 The powder was Brush-Wellman structural powder, SP-200-F, having particle sizes of 10 to $12 \mu \mathrm{m}$. This powder had been isostatically cold pressed into billets at $415 \mathrm{MPa}$ and then sintered for 4 hours at $1100^{\circ} \mathrm{C}$ in a vacuum of $0.013 \mathrm{~Pa}$. Although samples were prepared irom different billets of approximately $44 \mathrm{~mm}$ 
diameter, bulk densities were all within the range of $1.63 \pm 0.05 \mathrm{~g} / \mathrm{cm}^{3}$. Apparent porosities ranged from 10.5 to 13 percent. Samples from the various billets could therefore be assumed to have quite similar structure. Two difference sizes of specimens were used. Both were approximately $25.4 \mathrm{~mm}$ in diameter, but, Type A specimens were $2.54 \mathrm{~mm}$ thick and Type B specimens were $12.70 \mathrm{~mm}$ thick.

\subsection{Emissivity Measurements}

Emissivity measurements were obtained using the test set-up described in Reference 1. An induction coil was used to heat a sample contained in a quartz test chamber. A thermocouple embedded into a sample $25.4 \mathrm{~mm}$ in diameter by $2.54 \mathrm{~mm}$ thick was used to monitor temperature and to manually adjust the power on the induction generator. An infrared pyrometer sensing a wavelength of $160 \mu \mathrm{m}$ and having an emissivity adjustment was focused upon the specimen surface at an angle of about 30 degrees from normal. The sample was viewed through quartz windows to reduce interference of the infrared signal. The emissivity settings were adjusted during the course of the test to match indications from the infrared pyrometer with those from the thermocouple. The goal was to measure emissivity changes with time as the test progressed.

Table 1. Emissivity measurements for $600^{\circ} \mathrm{C}$ test.

\begin{tabular}{cccc} 
Time, minutes & Thermocouple, ${ }^{\circ} \mathrm{C}$ & $\begin{array}{c}\text { Infrared } \\
\text { Pyrometer. }{ }^{\circ} \mathrm{C}\end{array}$ & Emissivity \\
\cline { 2 - 3 } 0 & 600 & 602 & 0.24 \\
12 & 596 & 602 & 0.25 \\
15 & 600 & 602 & 0.27
\end{tabular}

First temperature decay occurred at this time.

$\begin{array}{llll}0 & 600 & 602 & 0.29 \\ 12 & 605 & 602 & 0.31 \\ 17 & 602 & 602 & 0.36 \\ 22 & 600 & 602 & 0.49 \\ 24 & 604 & 602 & 0.85 \\ 25 & -- & 602 & 0.93\end{array}$

The results from a sample tested at $600^{\circ} \mathrm{C}$ are summarized in Table 1. Emissivity was initially measured as 0.24 at the beginning of the test. There was a gradual increase to a value of 0.27 after 15 minutes. The test 




Figure 1. Temperature decay curves measured for a sample of porous beryllium reacted in steam at $600^{\circ} \mathrm{C}$. First cooling after 15 minutes and second cooling after 40 minutes. 
was then interrupted and a temperature decay occurred as shown in Figure 1. The steam supply was shut off and a minimum flow of argon of about 0.2 liters/minute was maintained during the cool-down. The sample was then reheated to $600^{\circ} \mathrm{C}$ in steam. Measured emissivity values continued to gradually increase and reached values of near 0.50 after another 22 minutes. The sample had by then developed a pinkish color. Within three minutes the samples became red and the emissivity settings had to be increased to 0.93 to maintain a match between the thermocouple and infrared pyrometer. Power and steam supply to the sample was then shut off and a second temperature decay obtained. This time-temperature plot is also included in Figure 1.

The trend of increasing emissivity with time shown in Table 1 agrees with some emissivity changes reported in the literature. Data compiled by Touloukian and DeWitt ${ }^{2}$ show progressively higher emissivity values for tungsten with 30 percent and 45 percent porosity compared to polished fully dense tungsten. Oxidation can also increase emissivity. These same authors show that polished, grit blasted and oxidized niobium at $800^{\circ} \mathrm{C}$ provide emissivities (hemispherical total emittance) of about $0.15,0.30$, and 0.70 , respectively. An example is also given whereby emissivity (normal total emittance) for beryllium metal increased from 0.5 to 0.9 when heated from $900^{\circ} \mathrm{C}$ to $1200^{\circ} \mathrm{C}$, and remained at the latter valued when cooled back to $900^{\circ} \mathrm{C}$. This same reference also shows that the normal spectral emittance of beryllium oxide is quite dependent upon minor material differences. Emittance values were shown to vary from less than 0.05 to 0.55 at the wavelength corresponding to our experiment. Direct comparisons of emissivity values are complex. However, a trend of higher emittance with the development of additional porosity or oxidation seems logical.

An increase in emissivity, as indicated above, and an increase in surface area due to sample swelling would increase radiative heat losses from a sample. This effect would oppose the onset of a self-sustaining reaction. Possible influences upon the onset of thermal instability may therefore be higher reaction rates due to greater internal reaction with time, or invalid temperature indications for the inductively heated specimens. Subsequent information presented from radiatively heated specimens shows a) there is some increase in sample reaction rates with time, but more importantly, b) the embedded thermocouple losos contact with the specimen as the sample swells. This causes invalid temperature indications and an over-heating of samples tested with the induction heating method. This also raise some question about the integrity of emissivities measured during the latter stages of the test reported in Table 1.

\subsection{Radiatirely Heated Samples (Temperature Dependence)}

A series of the Type A (thin) specimens was tested in the resistance heated shel1 furnace to determine the temperature at which thermal instability developed. The purpose was to compare this temperature with the thermal instability temperature of $675^{\circ} \mathrm{C}$ determined for inductively heated specimens. One thermocouple, embedded in the specimen, supported the specimen in the test chamber. Two additional thermocouples were used. One monitored steam temperatures about four millimeters upstream from the specimen. The other measured temperatures near the inner diameter of the 


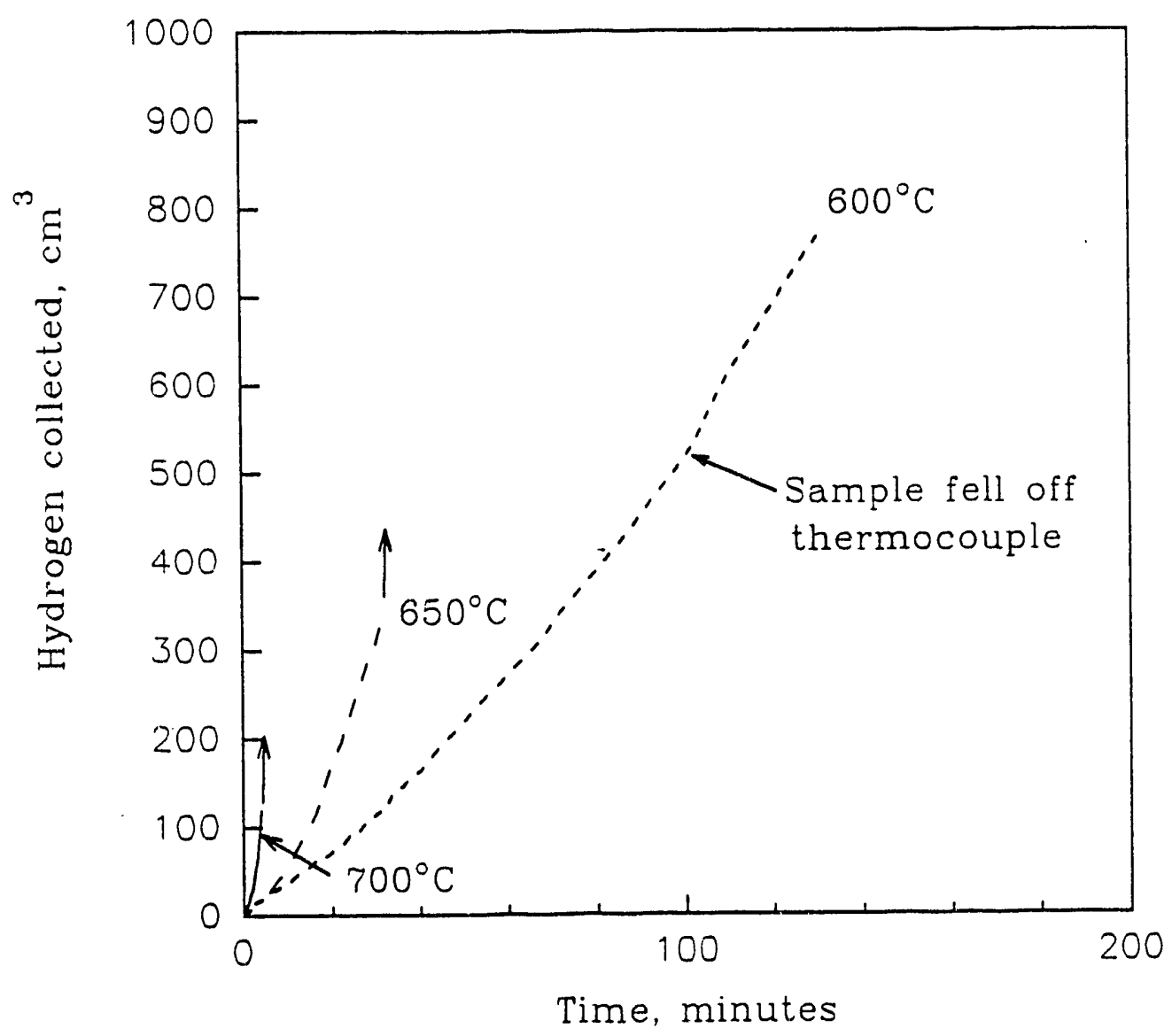

Figure 2. Hydrogen release from the 2.54-mm thick (Type A) specimens tested between $600^{\circ} \mathrm{C}$ and $700^{\circ} \mathrm{C}$. 
furnace chamber. The thermocouple embedded in the specimen was used to monitor and make minor power adjustments when changes in temperature by all thermocouples concurred. However, if the specimen thermocouple showed a sudden increase or changed in disagreement with the other thermocouples then no power correction was made. This method of testing provided a better match between the specimen and test environment temperatures and a lower possibility of overheating the sample compared to the induction heating method.

Figure 2 shows records of the amounts of hydrogen collected with time for Type A (thin) specimens tested between $600^{\circ} \mathrm{C}$ and $700^{\circ} \mathrm{C}$. The sample heated to $700^{\circ} \mathrm{C}$ developed a self-sustaining reaction within four minutes. The other thermocouples never registered temperatures exceeding $700^{\circ} \mathrm{C}$ during the test. They also lagged behind the specimen thermocouple during the temperature excursion. This demonstrates that chemical energy release from the bery 17 ium:steam reaction was responsible for the temperature excursion. The sample heated to $650^{\circ} \mathrm{C}$ was held at that temperature for 32 minutes. The sample then fell forward off the thermocouple and into a slightly higher temperature zone. Tie sample increased its reaction rate and within two to three minutes underwent a temperature excursion. The Type A sample tested at $600^{\circ} \mathrm{C}$ was releasing hydrogen at a linear rate after 96 minutes into the test. The sample then fell off of the thermocouple. The reaction rate for this sample in:reased, but, the sample did not develop a self-sustaining reaction. Results from the larger Type B.specimens tested between $400^{\circ} \mathrm{C}$ and $600^{\circ} \mathrm{C}$ are shown in Figure 3 . Hydrogen release was linear during the latter stages of the $600^{\circ} \mathrm{C}$ test and was terminated after 62 minutes. Hydrogen release initially appeared parabolic but then became linear for both the 3 -hour $400^{\circ} \mathrm{C}$ and 2 -hour $500^{\circ} \mathrm{C}$ tests.

This test series has shown two things: a) thermocouples that are firmly embedded into samples of porous beryllium will become loose as the reaction with steam proceeds, and b) the terperature at which 88 percent dense beryllium develops a self-sustaining reaction in steam is near $675^{\circ} \mathrm{C}$. We know that porous beryllium swells and develops additional porosity as it reacts. "This causes thermocouple contact with the specimen to degrade. Erroneously low readings result as the thermocouple junction is cooled by steam. In our previous tests using induction heating, we responded by increasing power levels which initiated thermal instability. This explains the delayed, or time-dependent, onset of thermal instability and the geometry effect that we initially believed to have happened in our previous study. But in reality, samples were actually over-heated and this was dependent upon time. The rate for sample swelling is temperature dependent, hence, it would take longer for thermocouples to provide incorrect indications at lower temperatures. Thermocouples are also embedded more deeply into larger specimens providing better security, again, increasing the time required to obtain invalid temperature indications. Temperatires near the wall of the test chamber, or three to four centimeters in front of the specimen, in the radiatively heated set-up were about $20^{\circ} \mathrm{C}$ to $25^{\circ} \mathrm{C}$ higher than at the center of the gas stream where the specimen was located. Therefore, in conclusion, the actual temperature at which this material becomes unstable is between $650^{\circ} \mathrm{C}$ and $675^{\circ} \mathrm{C}$. 


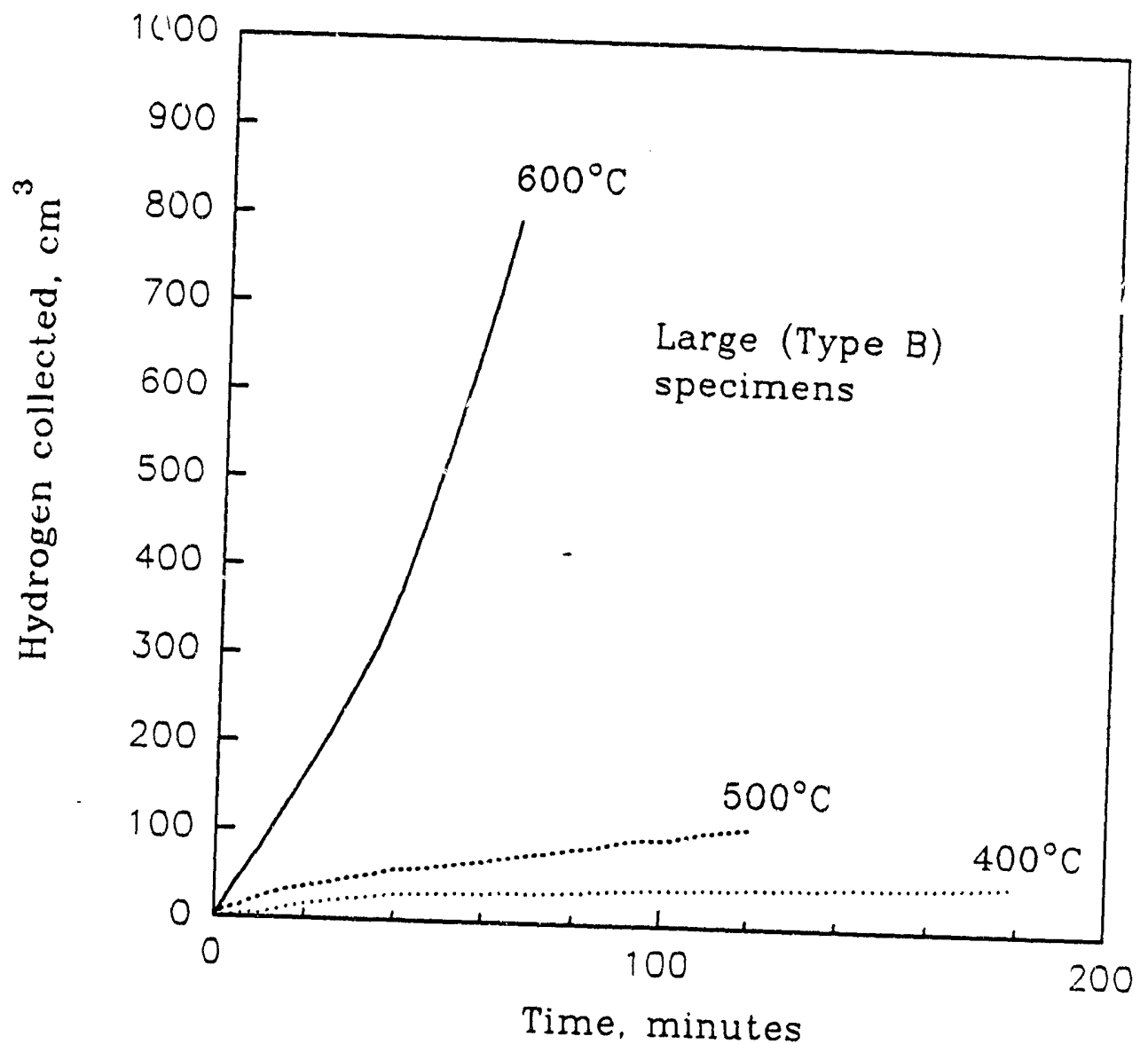

Figure 3. Hydrogen release from the $12.70-\mathrm{mm}$ thick (Type B)
specimens tested at $400^{\circ} \mathrm{C}, 500^{\circ} \mathrm{C}$, and $600^{\circ} \mathrm{C}$. 


\subsection{Radiatively Heated Samples (Geometry Dependence)}

Geometric effects upon reaction rates are provided from tests of samples of both Type $A$ and Type $B$ at $6100^{\circ} \mathrm{C}$. Hydrogen releases with time are shown for these samples ir Figure 4 . We used releases during the first hour to evaluate relative reaction rates with respect to initial surface area and sample mass. The comparison between these two samples is given in Table 2 . The Type B specimen had an external surface area of $20.3 \mathrm{~cm}^{2}$ compared to $12.2 \mathrm{~cm}^{2}$ for the Type A specimen. This is a ratio of 1.66 . The mass of the Type $B$ was $10.206 \mathrm{~g}$ and the Type A specimen was $2.023 \mathrm{~g}$. This provides a ratio of 5.05 . Table 2 shows that the quantity of hydrogen generated by the Type $B$ specimen relative to the Type A specimen increased from 1.9 to 2.7 over the duration of the tests. This shows that surface area provides the better parameter upon which to base reaction rates. However, there is an increasing dependence upon sample mass with time. The curves in Figure 4 also show an increasing release with time. This would correspond with the development of additional porosity and greater internal access of steam resulting in a larger proportion of the reaction taking place within the specimen.

Table 2. Influence of specimen geometry upon hydrogen production.

\begin{tabular}{cccc}
$\begin{array}{c}\text { Time, } \\
\text { minutes }\end{array}$ & $\begin{array}{c}\text { Volume, } \mathrm{cm}^{3} \\
\text { Type A Specimen }\end{array}$ & $\begin{array}{c}\text { Volume, } \mathrm{cm}^{3} \\
\text { Type B Specimen }\end{array}$ & $\begin{array}{c}\text { Ratio: } \\
\text { Type B/Type A }\end{array}$ \\
0 & 0 & 0 & - \\
5 & 27 & 50 & 1.9 \\
10 & 43 & 95 & 2.2 \\
20 & 86 & 195 & 2.3 \\
30 & 135 & 300 & 2.2 \\
40 & 193 & 435 & 2.3 \\
50 & 259 & 615 & 2.4 \\
60 & 320 & 820 & 2.6 \\
65 & 352 & 935 & 2.7 \\
\hline
\end{tabular}

\section{\.5 Temperature Dependence of Reaction Rate}

Samples were tested at temperatures from $400^{\circ} \mathrm{C}$ to $700^{\circ} \mathrm{C}$ in the resistance heated furnace. This extends below temperatures obtainable with the induction heating system. A summary of the test data acquired from radiatively heated specimens are given in Table 3 . This additional 
Table 3. Test data from porous beryllium in steam.

\begin{tabular}{|c|c|c|c|c|c|c|}
\hline Temp. ${ }^{\circ} \mathrm{C}$ & $\begin{array}{l}\text { Heating } \\
\text { Method }\end{array}$ & $\begin{array}{l}\text { Specimen } \\
\text { Iype }\end{array}$ & $\begin{array}{l}\text { Time, } \\
\text { minutes }\end{array}$ & $\begin{array}{l}\text { Reaction } \\
\text { Rate, } \\
\text { liters, } \text { lim }^{2} \text { S }\end{array}$ & \multicolumn{2}{|c|}{$\begin{array}{c}\text { Measured } \\
\text { Emissivity }\end{array}$} \\
\hline 557 & Inductive & A & 4 & $5.2 E-2$ & &.- \\
\hline 649 & Same sample & A & 6.5 & $1.6 \mathrm{E}-1$ & 0.14 & -0.23 \\
\hline 600 & Inductive & A & 15 & $3.3 E-2$ & 0.24 & -0.27 \\
\hline 600 & Same sample & $A$ & 25.5 & $8.8 \mathrm{E}-2$ & 0.29 & -0.93 \\
\hline 696 & Radiative & A & 4 & $4.1 E-1$ & & -- \\
\hline 656 & Radiative & A & 32 & $1.8 E-1$ & & $\cdots$ \\
\hline 594 & Radiative & A & 96 & $7.0 E-2$ & & $-\cdot$ \\
\hline 595 & Radiative & B & 65 & $\begin{array}{c}1.0 E-1 \\
(6.0 E-2)^{a}\end{array}$ & & $\cdots$ \\
\hline 494 & Radiative & B - & 120 & $\begin{array}{c}7.7 E-3 \\
(4.6 E-3)^{a}\end{array}$ & & $\cdots$ \\
\hline 395 & Radiative & B & 180 & $\begin{array}{c}2.4 E-3 \\
(1.5 E-3)^{a, b}\end{array}$ & & $\ldots$ \\
\hline \multicolumn{7}{|c|}{$\begin{array}{l}\text { aThe rate for the } 594^{\circ} \mathrm{C} \text {-Type } A \text { was } 60 \% \text { of that for the } 595^{\circ} \mathrm{C} \text { - } \\
\text { Type } B \text { test at } 65 \text { minutes. This correction was therefore } \\
\text { applied to all Type } B \text { specimens. }\end{array}$} \\
\hline
\end{tabular}

information has been combined with previous $7 y$ reported data $a^{1,3-4}$ and is shown in Figure 5. Data obtained for the porous beryllium from the two different methods of sample heating show good agreement. The one datum point for the $700^{\circ} \mathrm{C}$ induction test seems too high, but it is also probably the one with the greatest uncertainty. The rapid onset of thermal instability causes higher uncertainties in time and temperature. Reaction rates for the porous beryllium are about 50 and 100 times higher than dense beryllium at $700^{\circ} \mathrm{C}$ and $600^{\circ} \mathrm{C}$, respectively, and about one-fourth of the rates obtained for plasma sprayed samples. With the incorporation of the new data, the slope for the porous beryllium on the Arrhenius plot does not lie parallel to that for dense beryllium. Increasing contributions from internal reaction are likely responsible for this behavior. We have fit the data for the porous beryllium to an Arrhenius relationship for temperatures from $400^{\circ} \mathrm{C}$ to $700^{\circ} \mathrm{C}$. This relationship is shown below as Equation (1). 


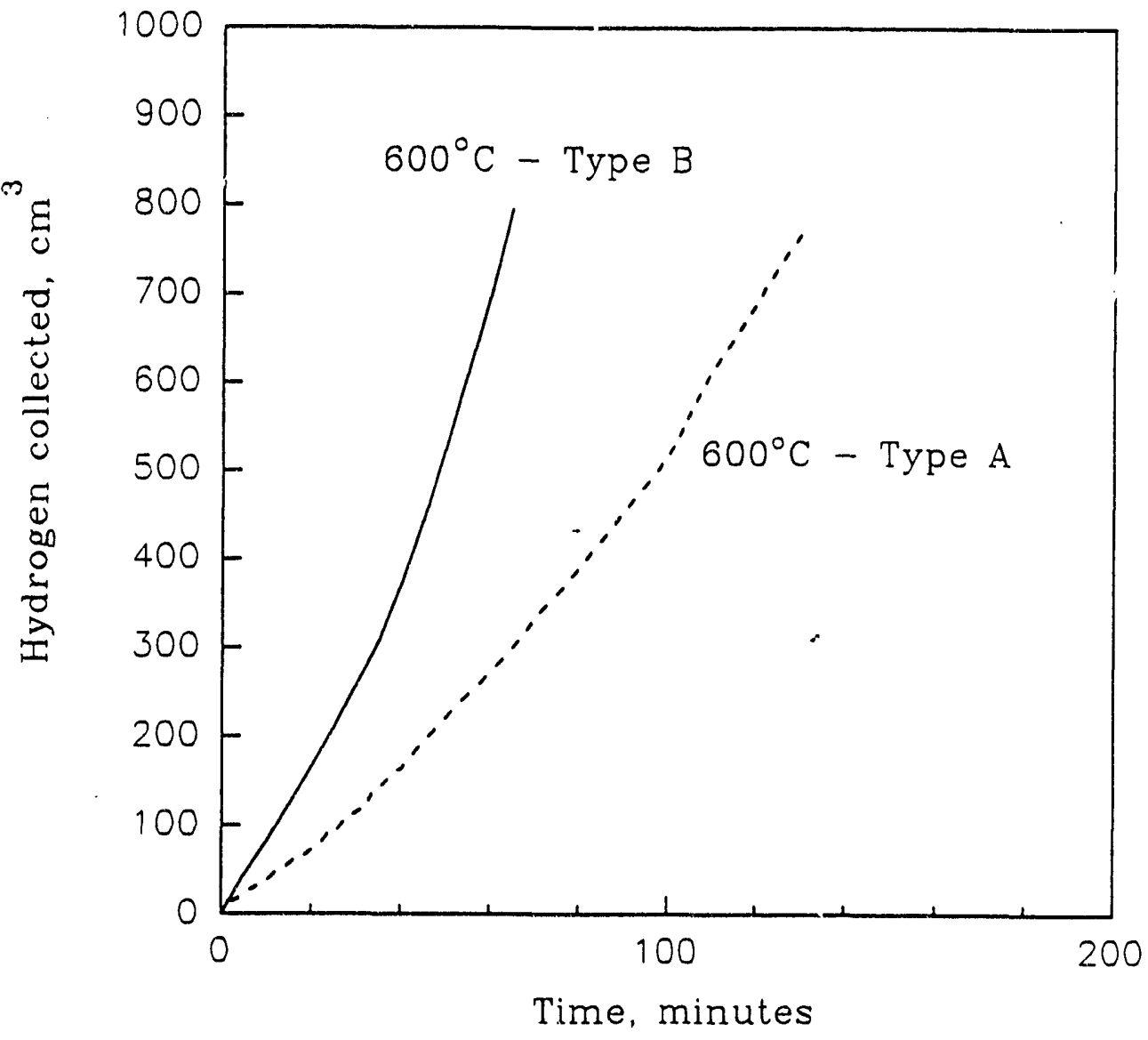

Figure 4. Hydrogen production from specimens of two different geometries at $600^{\circ} \mathrm{C}$. Small specimen (Type A) is $2.54 \mathrm{~mm}$ thick. The larger specimen (Type B) is $12.70 \mathrm{~mm}$ thick. 


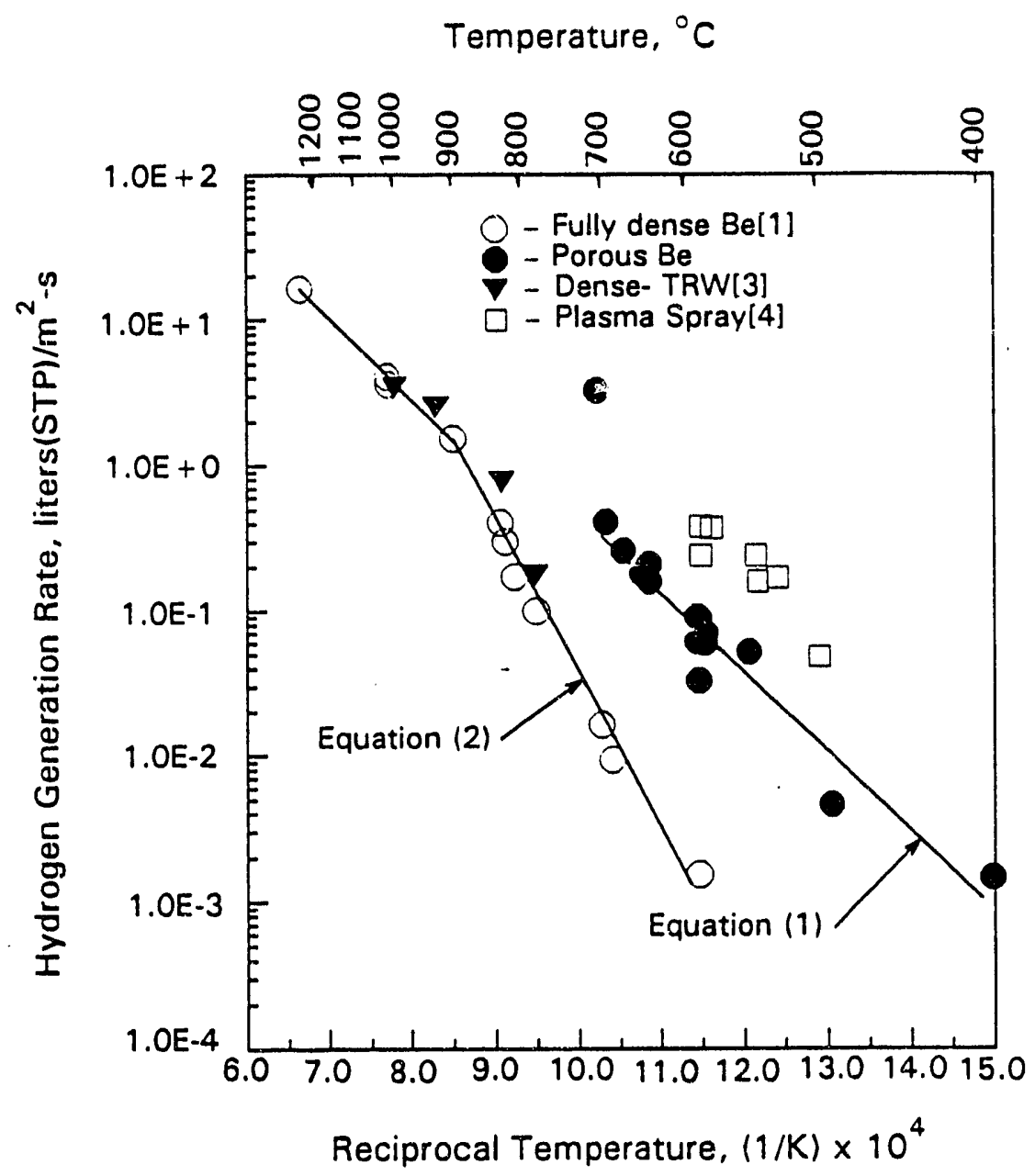

Figure 5. Current data from the porous beryllium combined with previously reported data for porous beryllium, dense beryllium, ${ }^{1,3}$ and plasma sprayed beryllium. ${ }^{4}$ 
The datum point at the lowest temperature, i.e., $400^{\circ} \mathrm{C}$, appears to 1 ie above the curve determined for the Arrhenius relationship for the porous beryllium in Figure 5. If this is true, linear extrapolation of the curve for dense beryllium to temperatures below $600^{\circ} \mathrm{C}$ could result in values which are too low. We propose that reaction rates for dense beryllium below $600^{\circ} \mathrm{C}$ be represented by $1 / 100$ th of the reaction rates of porous beryllium, i.e., Equation (1), to provide a factor of conservatism.

\subsection{Permeability Keasurements}

Permeability measurements were made on a sample of the porous beryllium using procedures similar to those described in ASTM Standard Practice C 577 . The sample was a Type A specimen with a 25.4-mm diameter and a $0.52-\mathrm{mm}$ thickness. This sample was sealed in a chamber and nitrogen was used as the penetrating gas. The flow rate( $Q)$ was varied from 34.4 to $275 \mathrm{~cm}^{3} / \mathrm{min}$. The upstream pressure varied from 34.47 to $347.7 \mathrm{kPa}$ above ambient, i.e., 5 psig to 50 psig. These tests were performed at room temperature and the viscosity of nitrogen was taken as 0.01765 centipoise. Calculations of the permeation constant were made based upon Equation (4).

$K($ millidarceys $)=(M Q L) /(A \Delta P) \times 1000$

where $M$ is the viscosity of the gas (centipoise), $Q$ is flow rate $\left(\mathrm{cm}^{3} / \mathrm{s}\right)$, $L$ is sample length $(\mathrm{cm}), A$ is sample area $\left(\mathrm{cm}^{2}\right), \Delta P$ is the absolute pressure drop across sample (atm.).

Results from this test were used to extrapolate back to a reciprocal pressure of zero to provide a constant $\left(K_{a}\right)$ for this material of 0.98 (millidarceys). Permeability for other gases, e.g., steam, may be obtained by substituting the viscosity of that gas into Equation (4). This relationship could be used to calculate steam penetration into porous beryllium. An application could be calculations of steam penetration and reaction within porous beryllium in breeder blankets.

\subsection{Volatility Measurements}

Differences in test configurations have made the direct comparisons of volatility data difficult. The test chamber in the electrical resistance heated furnace was positioned horizontally. The sample could not be removed without dislodging oxide within the chamber. Volatilized products were therefore collected only from the two condenser chambers located downstream. The deposition rates on the two condenser chambers and the flux from the specimen based upon the beryllium collected from these two components are shown below in Table 4. 
Table 4. Summary of volatilization results.

\begin{tabular}{cccc} 
Temp.,${ }^{\circ} \mathrm{C}$ & $\begin{array}{c}\text { Deposition rate } \\
\text { first condenser } \\
\left(\mathrm{g} / \mathrm{m}^{2}-\mathrm{s}\right)\end{array}$ & $\begin{array}{c}\text { Deposition rate } \\
\text { second condenser } \\
\left(\mathrm{g} / \mathrm{m}^{2}-\mathrm{s}\right)\end{array}$ & $\begin{array}{c}\text { Flux from } \\
\text { specimen, } \\
\left(\mu \mathrm{g} / \mathrm{m}^{2}-\mathrm{s}\right)\end{array}$ \\
600 & $8.0 \mathrm{E}-6$ & $2.5 \mathrm{E}-6$ & 132 \\
$500 \& 400$ & $8.6 \mathrm{E}-7$ & $3.1 \mathrm{E}-7$ & 14 \\
\hline
\end{tabular}

These values are in reasonable agreement with the flux values which we have previously reported. ' The values reported for temperatures below $800^{\circ} \mathrm{C}$ for dense bery 11 ium were generally below $100 \mu \mathrm{g} / \mathrm{m}^{2}-\mathrm{s}$. The above information is useful as an addition to the beryllium volatility database at the INEL. This information will be used in modeling the distribution of beryllium for accident scenarios to determine possible dose exposures for toxicity considerations.

\section{REFERENCES}

1. G. R. Smolik, B. J. Merrill, and R. S. Wallace, "Implications of beryllium: steam interactions in fusion reactors", Presented at the Fifth International Conference on Fusion Reactor Materials held Nov. 17-22, 1991 in Clearwater, Florida also to be published in $\mathrm{J}$. Nuclear Material.

2. Y. S. Touloukian and D. P. DeWitt, Thermophysical Properties of Matter: Volume 7 "Thermal Radiative Properties -- Metallic Elements and Alloys", New York: Plenum, 1970.

3. J. L. Blumenthal and M. J Santy, "An Experimental Investigation of the Behavior of Beryllium Simulated Launch Pad Abort Environments", TRW Systems, Contract No. 82-6211, Sandia Corporation Rep. SCDC-65-1637 (1965).

4. G. R. Smolik, ITER/US/92/PF-5, "Test Results from Plasma-Sprayed Bery11ium". March 16, 1992. 
DATE

FILMED

$01 / 10 / 93$ 
